\title{
A Review of Modelling of Photovolaic Solar Cell for Maximum Power Point Tracking
}

\author{
Ankita Pandey ${ }^{1}$, Dr. Dharmendra Kumar Singh ${ }^{2}$
}

\begin{abstract}
In recent years, the use of solar energy become an alternating source of energy of great importance. Several researches and efforts have been concentred on the improvement of the efficiency of photovoltaic system. Although solar energy is available throughout the day its insolation varies from morning to evening and with changing climate conditions. As the efficiency of solar PV panel at any given period of time. Several types of maximum power point tracking (MPPT) technique are proposed for the purpose. In this paper, MPPT has been studied and is undertaken for their theoretical verification and graphical representation.
\end{abstract}

Keywords: MPPT, PV panel, Photovoltaic system

\section{Introduction}

Solar energy is one of the most important energy source that have been increased the attention in recent year. Solar energy is costless; it has the larger availability as compare to other energy source. Solar energy is clean and free of emissions, since it is does not produce any type of harmful product which affects the nature. There are many application field of conversion of solar energy into electrical energy [1]. Recently, there has been significant environment and motivation to shift domestic power generation to renewable source such as wind and solar. Solar power is an attractive option because of large amount of power is available in incident sunlight. The most available solar technology is photovoltaic (PV) solar cell which operates best on bight day with little or no obstruction to incident sunlight. Frequent overcast days and partial obstructions such as tree limbs or neighbouring buildings limit the efficiency and reliability of solar power. This study is motivated by the need to optimize solar array performance for rapidly varying environmental conditions[2].

Because of the photovoltaic nature of solar panels, the I-V curves depend nonlinearly on temperature and irradiance levels. Therefore, the operating current and voltage, which maximize power output will change with environmental conditions. In order to maintain efficient operation despite environmental variations, one approach is to use a maximum power point tracking (MPPT) algorithm to dynamically tune either control current or voltage to the maximum power operating point.

A lot of research has been done to improve the efficiency of the PV modules. A number of methods to track the maximum power point of a PV module have been proposed to overcome the limitation of efficiency. A MPPT is used for extracting the maximum power from the solar PV module and transferring that power to the load.

In high power applications, the cost of MPPT control is low as against the cost of the photovoltaic (PV) array and power converters. However, for low power applications, the implementation cost of an MPPT algorithm is a concern. The most commonly used hill-climbing MPPT technique is the $\mathrm{P} \& \mathrm{O}$ algorithm. The $\mathrm{P} \& \mathrm{O}$ algorithm perturbs the operating point of the $\mathrm{PV}$ generator by increasing or decreasing a control parameter by a small amount and measuring the PV array output before and after the perturbation. If the power increases, the algorithm continues to perturb the system in the same direction; otherwise the system is perturbed in the opposite direction. Another very popular hill-climbing MPPT algorithm is the incremental conductance [3].

\section{Principle of Operation and Equivalent Circuit}

The operation of solar cell is similar to PN junction where there are diffusion current and dirft currents for direct and reverse polarization [4]. A solar panel cell basically is a p-n semiconductor junction. When exposed to the light, a DC current is generated. The generated current varies linearly with the solar irradiance. The equivalent electrical circuit of an ideal solar cell can be treated as a current source parallel with a diode shown in figure $1[5]$.

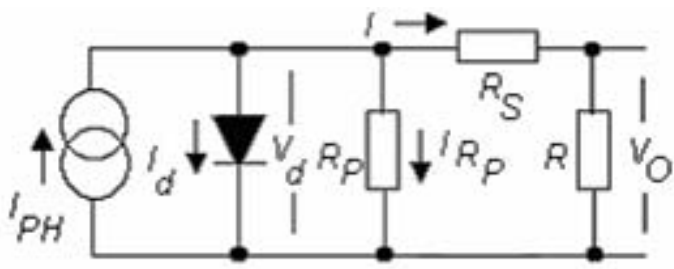

Figure 1: Equivalent Circuit of solar cell

In PV module number of solar cells connected in series $(\mathrm{Ns}=36)$ and parallel $(\mathrm{Np}=1)$ for obtaining the desired voltage and current output levels. Each solar cell is basically a p-n diode. As sunlight strikes a solar cell, the incident energy is converted directly into electrical energy without any mechanical effort[6].

From Fig. 1 shows the equivalent circuit of the solar cell, formed by a current source Iph in anti-parallel with diode driven by a current Id . The diode determines the currentvoltage output characteristic ( $\mathrm{IxV}$ ) and includes the voltage and current dependence of the cell in relation to the temperature. Based on this complete equivalent circuit, the output current of the solar cell can be calculated as,

$$
\mathrm{I}=\mathrm{I}_{\mathrm{ph}}-\mathrm{I}_{\mathrm{d}}-\mathrm{I}_{\mathrm{Rp}}
$$




\section{International Journal of Science and Research (IJSR) \\ ISSN (Online): 2319-7064}

Index Copernicus Value (2013): 6.14 | Impact Factor (2015): 6.391

where Iph is the current generated by irradiation also called short-circuit current, $I_{d}$ and $I_{R p}$ represent the diffusion current of the internal diode and the loss of current in Rp .

Considering the characteristic $\mathrm{IxV}$ the PN junction, the output current of the cell can be rewritten of the way:

$$
\mathrm{I}=\mathrm{I}_{\mathrm{ph}}-\mathrm{I}_{\mathrm{O}}\left(\mathrm{e}^{\frac{\mathrm{q}\left(\mathrm{V}_{\mathrm{o}+\mathrm{IRS}}\right)}{A K T}}-1\right)-\frac{\mathrm{Vo}+\mathrm{IRs}}{\mathrm{Rp}}
$$

where I and Vo are, respectively, the output current and voltage of the solar cell. Io is the reverse saturation current of the diode, $q$ is the charge of the electron, $A$ is the diode ideality factor, $K$ is the Boltzmann constant, $T$ is the temperature in ${ }^{\circ} K, R s$ and $R p$ represent the internal series and parallel resistances, respectively.

In the region of low voltage where the current through the equivalent circuit is very small, the parallel resistance has greater influence. This resistance is mainly due to the leakage of current in the cell surface, acting significantly only when the cells are in low brightness. The series resistance has origin in the metallic contacts and it offers significant influence on the performance of the solar cell.

A simplified model is shown in Fig. 2

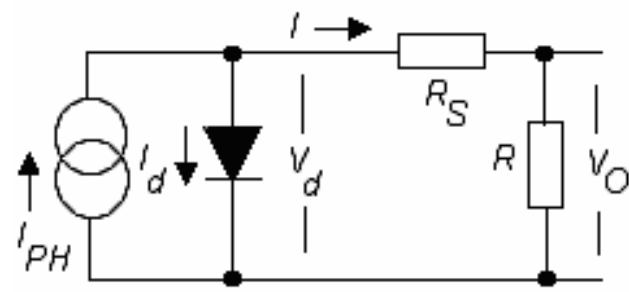

Figure 2: Simplified equivalent circuit of solar cell

$$
\mathrm{I}=\mathrm{I}_{\mathrm{ph}}-\mathrm{I}_{\mathrm{O}}\left[\left(e^{\frac{V o+R s I}{A V}} 1\right)\right]
$$

Where $V=\frac{\mathrm{KT}}{\mathrm{q}} \quad$ (thermal voltage), the equation of the output voltage of the cell will be given:

$$
\mathrm{Vo}=-\mathrm{IRs}+\frac{\mathrm{AKT}}{\mathrm{q}} \ln \left(\frac{\mathrm{Iph}-\mathrm{I}-\mathrm{Io}}{\mathrm{Io}}\right)
$$

The output power of the solar cell is calculated as:

$$
\mathrm{Po}=\mathrm{IVo}
$$

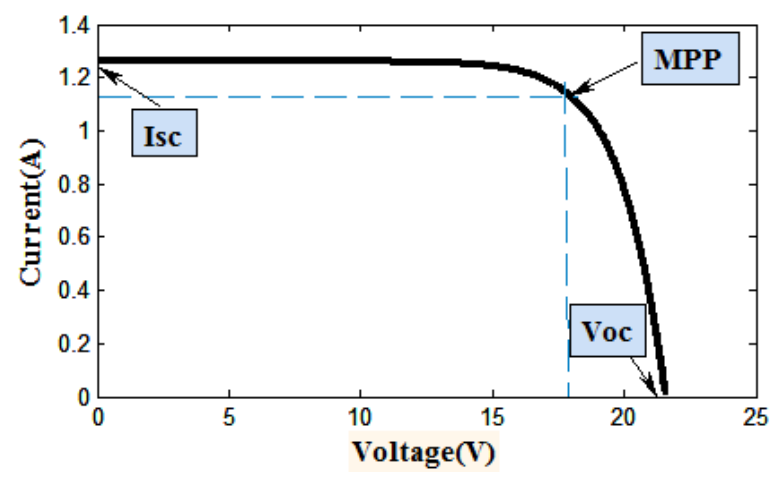

Figure 3: I-V chararateristics of PV cell

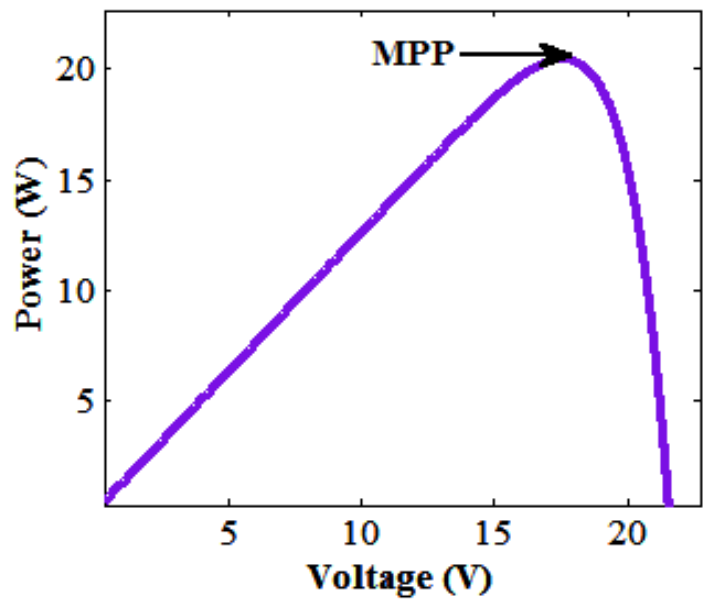

Figure 4: P-V characteristics of PV cell

\section{Conclusion}

In this paper we study the basic and principle of operation of maximum power point tracking. The maximum power point tracking (MPPT) is a technique used with wind turbine and photovoltaic (PV) solar systems to maximize power output. The solar cells have a complex relationship between temperature and total resistance that produces a non-linear output efficiency which can be analyzed based on I-V curve.

\section{References}

[1] Dr.Anil S. Hiwale, Mugdha V.Patil2,Hemangi Vinchurkar "An Efficient MPPT Solar Charge Controller" International Journal of Advanced Research in Electrical,Electronics and Instrumentation Engineering, Vol. 3, Issue 7, July 2014

[2] Steven L. Brunton, Clarence W. Rowley, Sanjeev R. Kulkarni, Fellow, IEEE, and Charles Clarkson "Maximum Power Point Tracking for Photovoltaic Optimization Using Ripple-Based Extremum Seeking Control" IEEE Transation on power electronics, VOL.25, NO.10, October 2010

[3] Dhananjay Choudhary, Anmol Ratna Saxena “ DC-DC Converter for MPPT of P-V System" International Journal of Emerging Technology and Advanced Engineering, Volume 4, Issue 7, July 2014

[4] P. C. M. Bernardo, Z. M. A. Peixoto and L.V. B. Machado Neto “ A High Efficient Micro-controlled Buck Converter with Maximum Power Point Tracking for Photovoltaic Systems" International Conference on Renewable Energies and Power Quality (ICREPQ'09) Valencia (Spain), 15th to 17th April, 2009

[5] A.Pradeep Kumar Yadav, S.Thirumaliah, G.Haritha "Comparison of MPPT Algorithms for DC-DC Converters Based PV Systems" International Journal of Advanced Research in Electrical, Electronics and Instrumentation Engineering, Vol. 1, Issue 1, July 2012

[6] D.Shankar, and P.S.Kulkarni "Soft Switching Buck Converter for Battery Charging With MPPT" International Journal of ChemTech Research, Vol.5, No.2, pp 947-956, April-June 2013 


\section{International Journal of Science and Research (IJSR) \\ ISSN (Online): 2319-7064}

Index Copernicus Value (2013): 6.14 | Impact Factor (2015): 6.391

\section{Author Profile}

Ankita Pandey is pursuing m.tech (power system) from Dr. C.V. Raman University Bilaspure. She has completed B.E. (Electrical Engineering) From C.S.V.T.U. Bhilai (C.G.), India

Dr. Dharmendra Kumar Singh: H.O.D. Electrical and Electronics department, Dr. C.V. Raman university, bilaspure. Recently he has done his Phd from Dr. C.V.Raman university bilaspure (C.G.), India 